\title{
Editorial: Articles and Particles
}

Ezra Pound wrote to T. S. Eliot on I 8 January 1940: 'The Yanks are publishing a goddam series on Philosophers, beginning, i.e. begun, with Dewey, Santayana second. I could probably chew the ear off some of the fatheads.' This buccaneering style of book reviewing has the reputation in the United States of being a typically British accomplishment, and in America, we are told, the Times Literary Supplement is eagerly combed for touches of elegant ill-will from literary London or of erudite envy from Oxford and Cambridge. Certainly there is a long and strong tradition of plain speaking among the lettered and learned in Britain and Ireland. Swift was a combatant as well as a war commentator in the Battle of the Books, and Byron's English Bards and Scotch Reviewers is supplemented by more than one digressive stanza in Don fuan:

John Keats, who was kill'd off by one critique, Just as he really promised something great,

If not intelligible, without Greek

Contrived to talk about the Gods of late,

Much as they might have been supposed to speak.

Poor fellow! His was an untoward fate;

'Tis strange the mind, that very fiery particle,

Should let itself be snuff'd out by an article.

These reflections and recollections are prompted by the severity and asperity of a review by Dr M. A. Stewart, Editor of Philosophical Books, in the May 1977 issue of his journal. Under the title 'Dead-born from the Press' he details what he sees as the manifold demerits of the Clarendon Press edition of Hume's The Natural History of Religion and Dialogues Concerning Natural Religion, and concludes:

This book should not have been let loose and is a great disservice to scholarship; for the sad irony is that it has actually created the need it was intended to fill. Our previous texts of both Hume works were good enough for salvation;... But now that the job has been, in Hume's phrase, botch'd and bungled, all of a sudden we do need an authoritative edition to replace it, to correct both the misrepresentations of Hume's text and the aspersions on the reliability of previous editors.

Ezra Pound wrote to Marianne Moore on 16 December 1918: 'You know, possibly, that I don't mind the natives' feelings, but I think when giving offence one should always be dead right, not merely defensible.' If Dr Stewart is dead right, he might well have used again a dart first sharpened for Robert Graves on Greek mythology: 'It is to be hoped that an erratum slip will be published as a companion volume.' 